\title{
MODELLING SEASONAL CHANGES OF LONGITUDINAL DISPERSION IN THE OKNA RIVER
}

\author{
Martin Manina ${ }^{凶}$, Peter Halaj, Luboš Jurík, Tatiana Kaletová \\ Faculty of Horticulture and Landscape Engineering, Slovak University of Agriculture in Nitra, Tulipanova 7, 949 76, Nitra, Slovakia
}

\begin{abstract}
Aim of study

The problem of investigation of pollution transport along watercourses is not new, but since it is so complex there is still space for fine-tuning in order to apply it to individual watercourses. This study presents an opportunity to determine a value of longitudinal dispersion and is focused on comparing seasonal variation of the longitudinal dispersion predetermined by natural conditions of the river aquatic zone.
\end{abstract}

\begin{abstract}
Material and methods
The dispersion of a pollutant tracer was simulated by HEC-RAS model and by one-dimensional advection-diffusion equation. Longitudinal dispersion coefficient was determined based on of tracer experiments ( $2 \mathrm{~kg} \mathrm{NaCl}$ in $101 \mathrm{H}_{2} \mathrm{O}$ ) carried out in March, August, and October 2019. Both methods were applied to the Okna River in the Eastern Slovak Lowland.
\end{abstract}

\begin{abstract}
Result and conclusions
Result showed that HEC-RAS modelling correlated to changes of dispersion and vegetation in the river. During the year, the longitudinal dispersion coefficient for Okna river estimated by the equation remained in a range from 0.093 to $1.08 \mathrm{~m}^{2} \cdot \mathrm{s}^{-1}$, and when estimated using the HEC-RAS, from 0.220 to $1.850 \mathrm{~m}^{2} \cdot \mathrm{s}^{-1}$. Results could represent different values of longitudinal dispersion simulated by the model or the equation. The obtained coefficients have a broad range of applications. The main use of these is as input data in the simulation of the spread of accidental pollution in rivers. Also, they can be applied to streams with similar characteristics. Results demonstrated an important role of seasonal variation of longitudinal dispersion coefficient that must be taken into account in the simulation of pollution spreading in rivers.
\end{abstract}

Keywords: longitudinal dispersion, HEC-RAS, tracer, field experiment

\section{INTRODUCTION}

With the development of civilization, river channels have been subject of large modifications (Nawiesniak, 2018). Water pollution accidents occur frequently, and in several cases, they caused significant damage in recent years (Gaiemo and Cheng, 2019). Freshwater is a scarce and valuable resource - one that can easily be contaminated. Once water is contaminated to the extent that it is considered "polluted", water quality is difficult and expensive to restore (Walker et al., 2019). The environmental protection, including protection of aquatic environment, in qualitative terms should consist in limiting emission of pollutants into the environment (Mosiej et al., 2019). Hydrologic models are often used to quantify these flow-ecology relationships and guide management actions. Traditional model calibration techniques typically focus on a best

凶e-mail: martinmanina@yahoo.com 
overall fit criterion that may not be suitable for environmental flow applied where certain elements of the flow regime exert a dominant influence on biotic composition (Parker et al., 2019). The HEC-RAS 4.0 model has been expanded to include a water quality component, which can simulate water temperatures and the movement of contaminants in rivers (Drake et al., 2010). One-dimensional (1-D) numerical models of solute transport in streams rely on the advection-dispersion equation, in which the longitudinal dispersion coefficient is an unknown parameter to be calibrated. Numerical models have been employed in engineering studies to predict the travel time and concentration of pollutants (Abderrezzak et al., 2015).

In the article, the authors determine a value of longitudinal dispersion of pollution in a small river and compare the seasonal variability of longitudinal dispersion predetermined by natural conditions of the river aquatic zone.

\section{MATERIAL AND METHODS}

\section{Case study area}

Okna is a river in the Eastern Slovak Lowland with a total length of $37 \mathrm{~km}$ (see: Fig. 1). It is a left - side tributary of Cierna Voda. Original shape of cross-sections was trapezoidal, with riverbed width $b=2 \mathrm{~m}$, height $h=2.5 \mathrm{~m}$ and bank slope $1: 1$. The measured discharge varied between $0.049 \mathrm{~m}^{3} \cdot \mathrm{s}^{-1}$ and $0.311 \mathrm{~m}^{3} \cdot \mathrm{s}^{-1}$ during the year. Manning's roughness coefficient determined based on field observations, for the part without vegetation and with vegetation cover, was $n=0.025$ and 0.045 , respectively (see: Fig. 2 and Fig. 3). Longitudinal channel bed slope of selected segment was $S o=0.002$, and the average water depth varied between $0.5 \mathrm{~m}$ and $0.89 \mathrm{~m}$ during the field measurement.

\section{Experimental design}

Length of the selected segment of river was $120 \mathrm{~m}$ and was divided into 3 parts with 4 cross-sections at the distances of $0 \mathrm{~m}, 60 \mathrm{~m}, 90 \mathrm{~m}$, and $120 \mathrm{~m}$ (see: Fig. 4). The $\mathrm{NaCl}$ tracer ( $2 \mathrm{~kg}$ of $\mathrm{NaCl}$ diluted in 101 of water) had been used to present increasing values of conductivity in the water. Tracer was injected straight into the flow in the middle of a cross-section 1. Same procedure was repeated 3 times in March, June and October 2019. The concentration of the tracer was measured in all profiles (see: Fig. 5-7) at the same time. Cross-section profiles and flow rate were measured for each profile and date, using the FlowTracker (by SonTec). Flow velocities and water depth were measured at every $30 \mathrm{~cm}$ of width, at two depths $(0.2 \mathrm{~h}$ and $0.8 \mathrm{~h})$.

Same boundary conditions were selected for all scenarios modelled in the HEC-RAS. Upstream boundary condition was set up at a flow hydrograph during the period, and downstream boundary was set at normal depth, which means energy slope. Normal depth was calculated for each profile based on the slope of the channel bed.

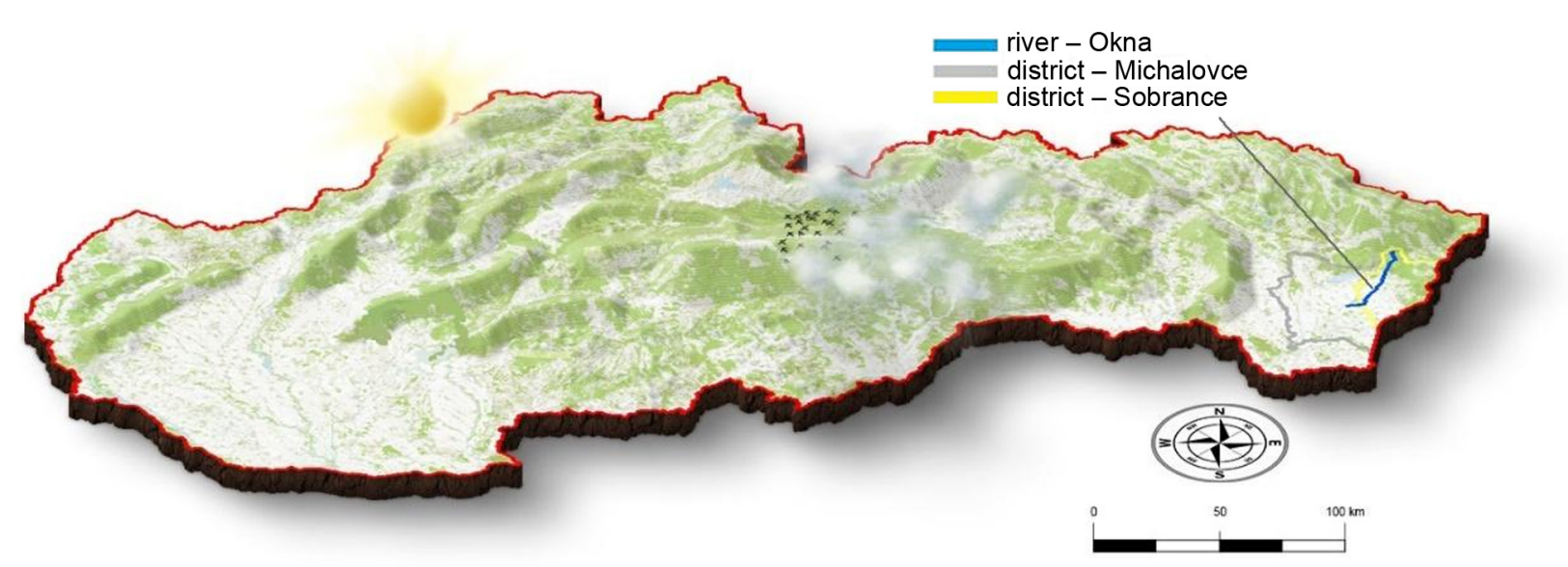

Fig. 1. Location of Okna river within Slovakia (Author, 2020) 


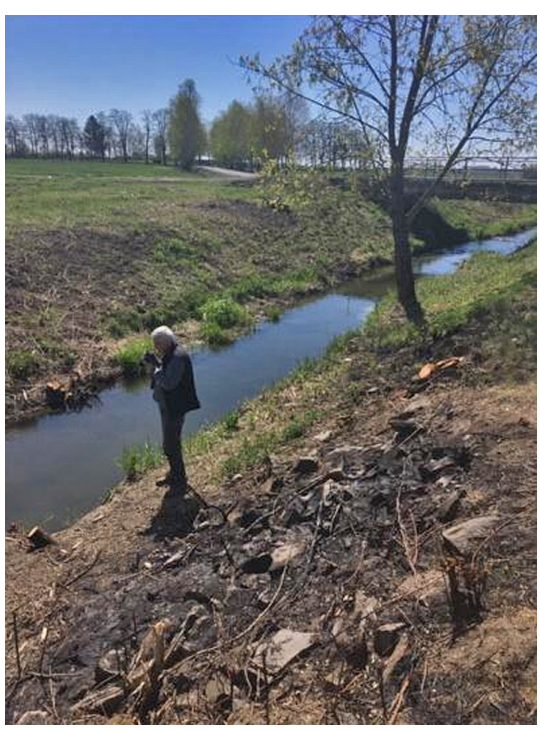

Fig. 2. Vegetation at Okna river, March 2019 (photo by: M. Manine)

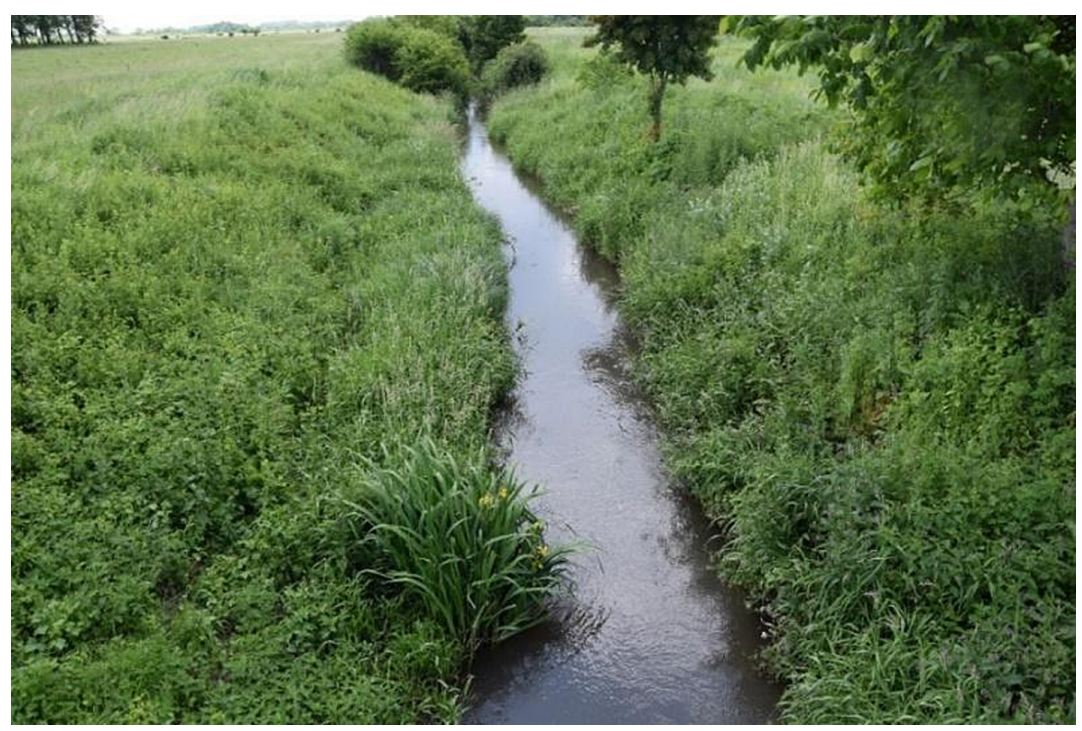

Fig. 3. Vegetation at Okna river, June 2019 (photo by: M. Manine)

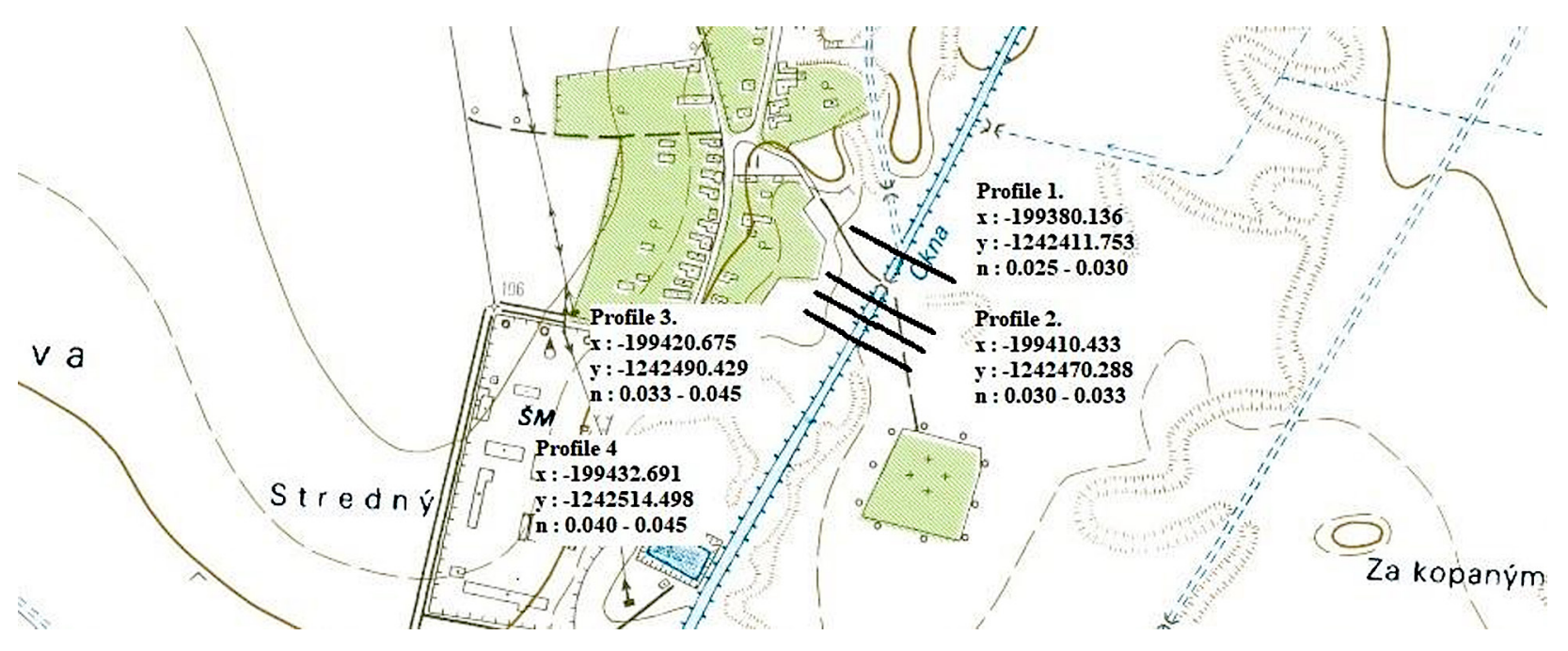

Fig. 4. Profile locations in S-JTSK coordinates system in the area of interest, with Manning roughness coefficient $n, 1: 7500$

$\mathrm{NaCl}$ is an electrolyte, which becomes sodium ions $\left(\mathrm{Na}^{+}\right)$and chloride ions $\left(\mathrm{Cl}^{-}\right)$when is dissolved in water. That is a corpuscle that conducts electricity, therefore the more of these ions contained in water, the more electricity is carried, and the higher the conductivity. Data Logger - WTW 2 FD451 (Multi 3410) was used for in situ measurement of temperature and electrical conductivity in $\mathrm{mS} \cdot \mathrm{cm}^{-1}$ in 10 -second intervals. Electrical conductivity output of data logger was transformed to $\mathrm{NaCl}$ concentration in $\mathrm{mg} \cdot \mathrm{l}^{-1}$ according to concentration curves. Concentration curves represent the correlation between the concentrations of different diluted salts and corresponding measured electrical conductivity. Curves were completed in the 
laboratory conditions with the respect of the field conditions (water sample taken before the measurement, stored and analyzed in appropriate temperature). The correlation between electrical conductivity and concentration of $\mathrm{NaCl}$ in Okna river may be calculated by the following equation:

$$
y=1 E-04 x-0.8674
$$

\section{Longitudinal dispersion coefficient calculation}

Although many researchers extensively studied longitudinal dispersion coefficients in simple-shape channels, the flow conditions in the more complex geometries are entirely different than those in simple channels (Hamidifar et al., 2015). Longitudinal dispersion is a complicated transport process, which is highly responsive to any hydrological, hydraulic, or vegetation change

103.42

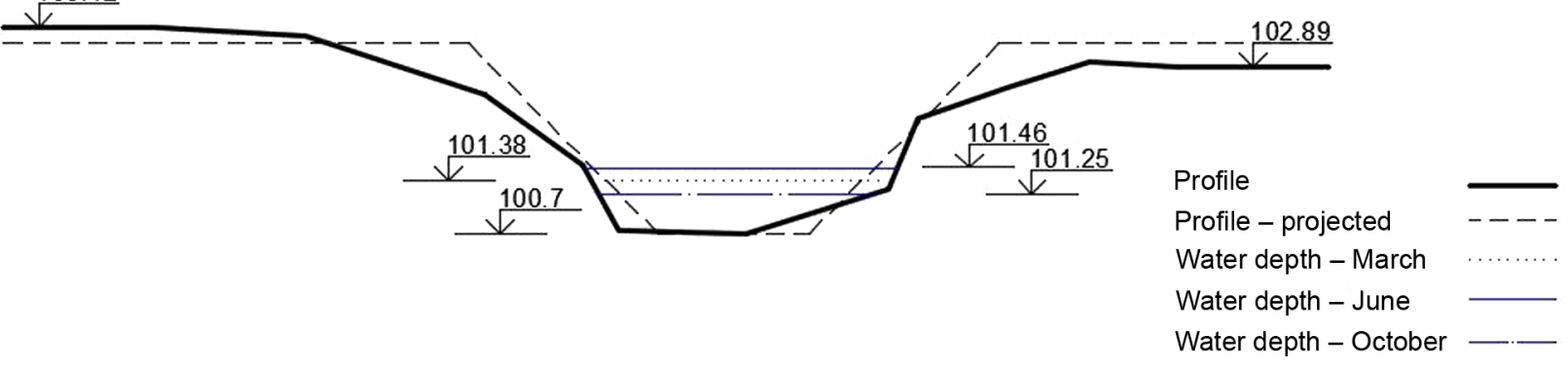

Fig. 5. Cross-section of the Okna river, profile No. 2, $60 \mathrm{~m}$ from injection, water depths in March, June and October

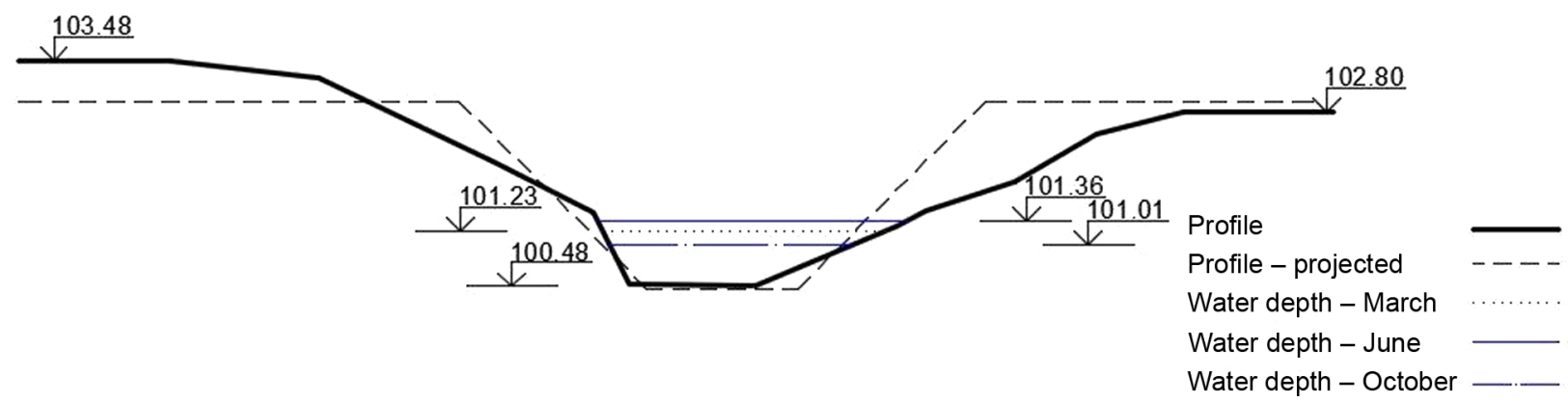

Fig. 6. Cross-section of the Okna river, profile No. 3, $90 \mathrm{~m}$ from injection, water depths in March, June and October

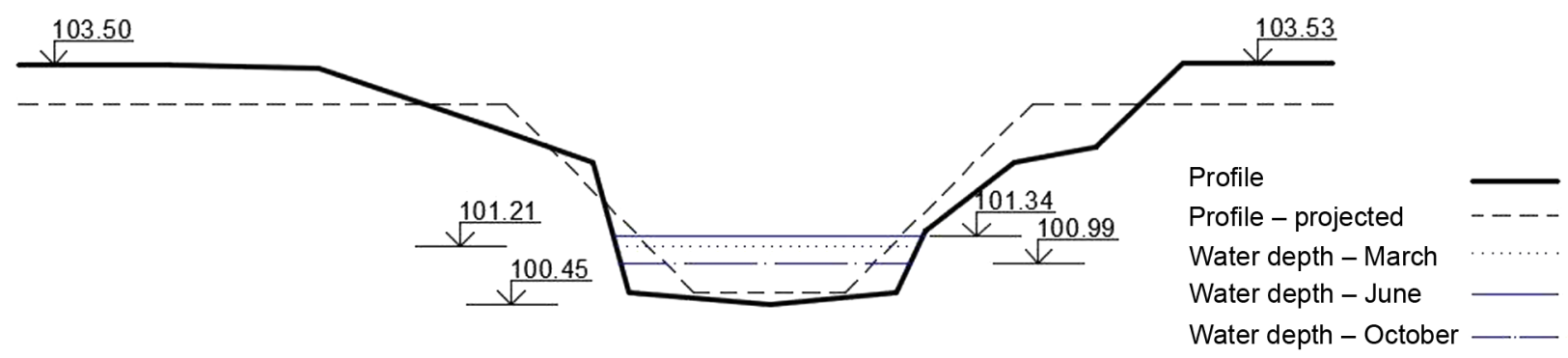

Fig. 7. Cross-section of the Okna river, profile No. 4, $120 \mathrm{~m}$ from injection, water depths in March, June and October 
(Taldei et al., 2010). Understanding the transport of matter (mass, momentum and heat) in the solvent (gas and liquid) is necessary in lots of applications, such as contamination control, sediment deposition, flow with vegetation, water intake, and thermal discharge (Wang et al., 2017). Description of dispersion process in surface stream is based on the one-dimensional advection-diffusion equation. It is the simplest mathematical formulation of this process from hydrodynamic point of view, as follows:

$$
\frac{\partial C}{\partial t}+v_{x} \frac{\partial C}{\partial x}=D_{x}\left(\frac{\partial^{2} C}{\partial x^{2}}\right)+M_{s}
$$

where: $t$ is time (s), $C$ is concentration of pollution $\left(\mathrm{kg} \cdot \mathrm{m}^{-3}\right), D_{x}$ is dispersion coefficient in the longitudinal direction $\left(\mathrm{m}^{2} \cdot \mathrm{s}^{-1}\right), v_{x}$ is flow velocity of water $\left(\mathrm{m} \cdot \mathrm{s}^{-1}\right), M_{\mathrm{s}}$ is a function representing the sources of pollution $\left(\mathrm{kg} \cdot \mathrm{m}^{-3} \cdot \mathrm{s}^{-1}\right), x$ is spatial coordinate - distance (m) (Sokac and Veliskova, 2019).

Analytical solution, assuming various simplifications of the (2) can be written in the form of one-dimensional equation (Fisher, 1979):

$$
C(x, t)=\frac{M}{2 A \sqrt{\pi D_{x} t}} \exp \left(-\frac{\left(x-v_{x} t\right)^{2}}{4 D_{x} t}\right)
$$

where: $C(x, t)$ is a mass concentration $\left(\mathrm{kg} \cdot \mathrm{m}^{-3}\right)$ in a place and time, $D_{x}$ is the longitudinal dispersion coefficient $\left(\mathrm{m}^{2} \cdot \mathrm{s}^{-1}\right), A$ is a discharge area in stream crosssection $\left(\mathrm{m}^{2}\right), M$ is a mass of a tracer $(\mathrm{kg}), x$ is distance $(\mathrm{m}), t$ is time $(\mathrm{s}), v_{x}$ is the mean flow velocity $\left(\mathrm{m} \cdot \mathrm{s}^{-1}\right)$.

\section{Hec-ras}

The U.S. Army Corps of Engineers River Analysis System (HEC-RAS) is software for performing 1-D steady flow, 1-D and 2-D unsteady flow river hydraulics calculations, quasi unsteady and full unsteady flow sediment transport, mobile bed modelling, water temperature analysis, and generalized water quality modelling (nutrient fate and transport). The first version of HEC-RAS was released in July of 1995. Software was developed at the Hydrological Engineering Centre (HEC), which is a division of the Institute for Water Resources. It includes numerous data entry capabilities, hydraulic analysis components, data stor- age and management capabilities, and graphing and reporting capabilities. Basic computational procedure of HEC-RAS for steady flow is based on solving the one-dimensional energy equation. Energy losses are evaluated by friction and contraction / expansion. Momentum equation may be used in situations where the water surface profile is rapidly varied. For unsteady flow, HEC-RAS solves the full, dynamic, 1-D Saint-Venant Equation using an implicit, finite difference method. HEC-RAS is equipped to model a network of channels, a dendritic system, or a single river reach. Certain simplifications must be made in order to model some complex flow situations using the HEC-RAS one-dimensional approach. It is capable of modeling subcritical, supercritical, and mixed flow regime flow along with the effects of bridges, culverts, weirs and structures.

Simulation of unsteady flow was performed on the basis of a cross-section data, and the Manning coefficient was calculated for bottom and banks, discharges, longitudinal slope, and boundary conditions. Simulation of unsteady flow within HEC-RAS makes it possible to analyze water quality parameters - temperature, consumption of oxygen, nitrates, nitrites, organic phosphate, and orthophosphates; to simulate a transport of pollutants, as well as set the boundary condition. Definition of water quality for each cell located between the profiles and amount of injected water with salt concentration were determined according to field data.

\section{RESULTS AND DISCUSSION}

Based on data from the measurements, coefficient of longitudinal dispersion has been determined using the HEC-RAS model, calculated with equation (3), and the two theories has been compared (see: Table 1). The injection of water and salt concentration followed profile and flow rate measurements. Basal concentration of $\mathrm{NaCl}$ used in water flow was $116.35 \mathrm{mg} \cdot \cdot^{-1}$ in March, $91.01 \mathrm{mg} \cdot \cdot^{-1}$ in June, and $128.21 \mathrm{mg} \cdot \cdot^{-1}$ in October, respectively. According to results of field measurements, we proceeded to modelling and calculation by equation (3) of longitudinal dispersion coefficient $D x$. Advantage of using HEC-RAS model in comparison with the numerical solution was ability to implement bed and bank roughness coefficient $-n$. 
Table 1. Values of longitudinal dispersion determined using equation (3) and HEC RAS model

\begin{tabular}{|c|c|c|c|}
\hline \multirow{2}{*}{ profile } & \multirow{2}{*}{$\begin{array}{c}\text { Month of } \\
\text { measurement }\end{array}$} & \multicolumn{2}{|c|}{$\begin{array}{l}\text { Longitudinal dispersion } \\
\text { coefficient } \mathrm{Dx}\left(\mathrm{m}^{2} \cdot \mathrm{s}^{-1}\right)\end{array}$} \\
\hline & & Equation (3) & HEC - RAS \\
\hline \multirow{3}{*}{$\begin{array}{l}\text { Profile } 2 \\
(60 \mathrm{~m})\end{array}$} & March & 0.093 & 0.220 \\
\hline & June & 0.139 & 0.820 \\
\hline & October & 0.248 & 0.345 \\
\hline \multirow{3}{*}{$\begin{array}{l}\text { Profile } 3 \\
(90 \mathrm{~m})\end{array}$} & March & 0.141 & 0.582 \\
\hline & June & 0.117 & 1.310 \\
\hline & October & 0.381 & 0.632 \\
\hline \multirow{3}{*}{$\begin{array}{l}\text { Profile } 4 \\
(120 \mathrm{~m})\end{array}$} & March & 0.187 & 0.801 \\
\hline & June & 1.163 & 1.850 \\
\hline & October & 1.098 & 0.703 \\
\hline
\end{tabular}

The onset of tracer concentration in March (see: Fig. 8) is very similar in all profiles as for other field measurements. Calculated and modelled decrease of concentration in profiles 2 and 3 corresponds to the measured values. Peak value was recorded almost at the same time in all cases. Apparent difference in decline in profile 4 was caused by vegetation in the stream and its effect on the water movement. Also, dilution of tracer within the water flow decreased $\mathrm{NaCl}$ concentration in profiles 3 and 4 .

The course of tracer modelled by HEC-RAS in June is the same as in March. Concentration measured in profiles 2 and 3 (60 m and $90 \mathrm{~m}$, respectively) closely match modelled and calculated values. This direct demonstration match was obtained by searching for an unknown longitudinal dispersion coefficient (see: Fig. 9). A slight deviation occurred again in profile 4, where the onset of increasing concentration value is relatively well captured, but there is observable deviation during the decrease progress.

Slight deviations can be observed in October in comparison to result of simulations and calculations in March and June. Especially the results of calculation by equation (3) present an earlier onset of concentration in all profiles (see: Fig. 10). The most visible difference is in profile 4 where in addition to the earlier onset and peak, also decrease progress is slower. Results of HEC-RAS modelling better correlate to the measured one. Nevertheless, onset and decrease demonstrate differences in profiles 3 and 4 .

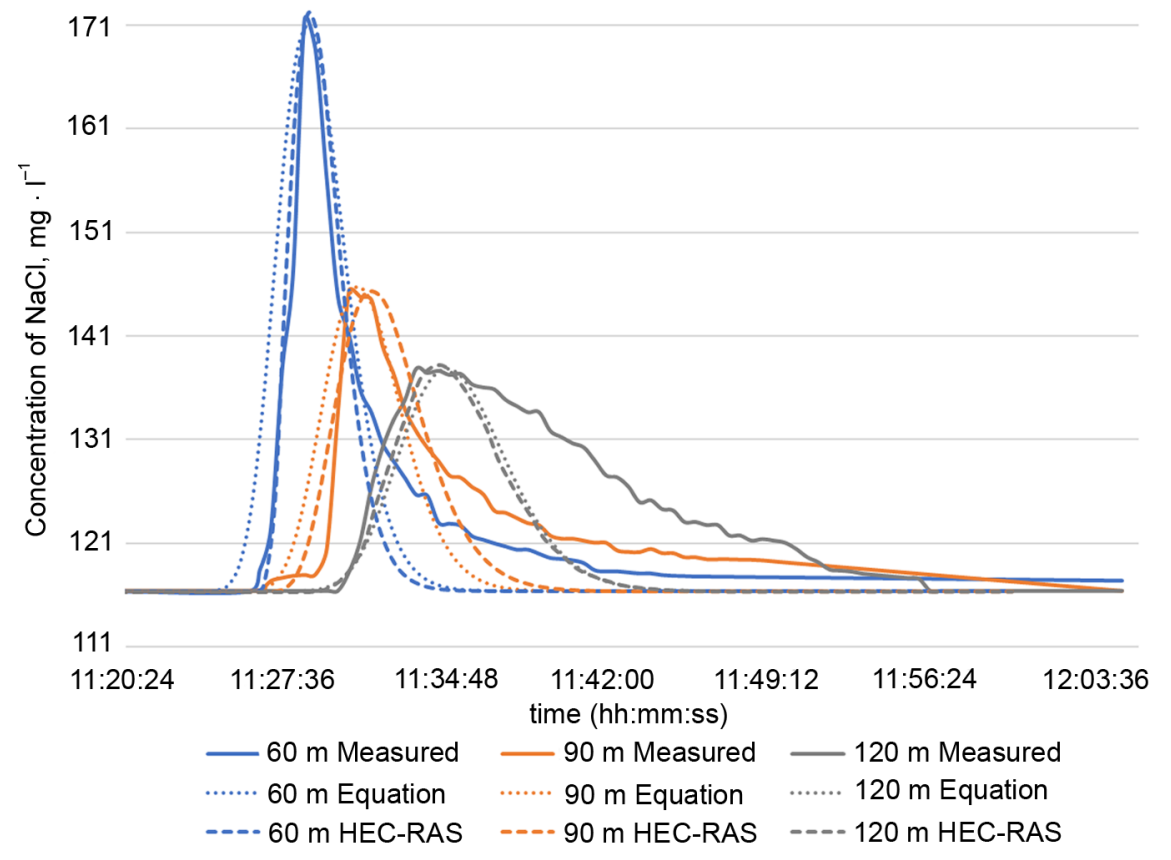

Fig. 8. The course of tracer over time in the Okna river, in March 2019; injected amount: $2 \mathrm{~kg} \mathrm{NaCl}$; distance from place of application: $60,90,120 \mathrm{~m}$; water flow $Q=0,155-0.195 \mathrm{~m}^{3} \cdot \mathrm{s}^{-1}$ 
Manina, M., Halaj, P., Jurík, L., Kaletová, T. (2020). Modelling seasonal changes of longitudinal dispersion in the Okna river. Acta Sci. Pol., Formatio Circumiectus, 19 (1), 37-46. DOI: http://dx.doi.org/10.15576/ASP.FC/2020.19.1.37

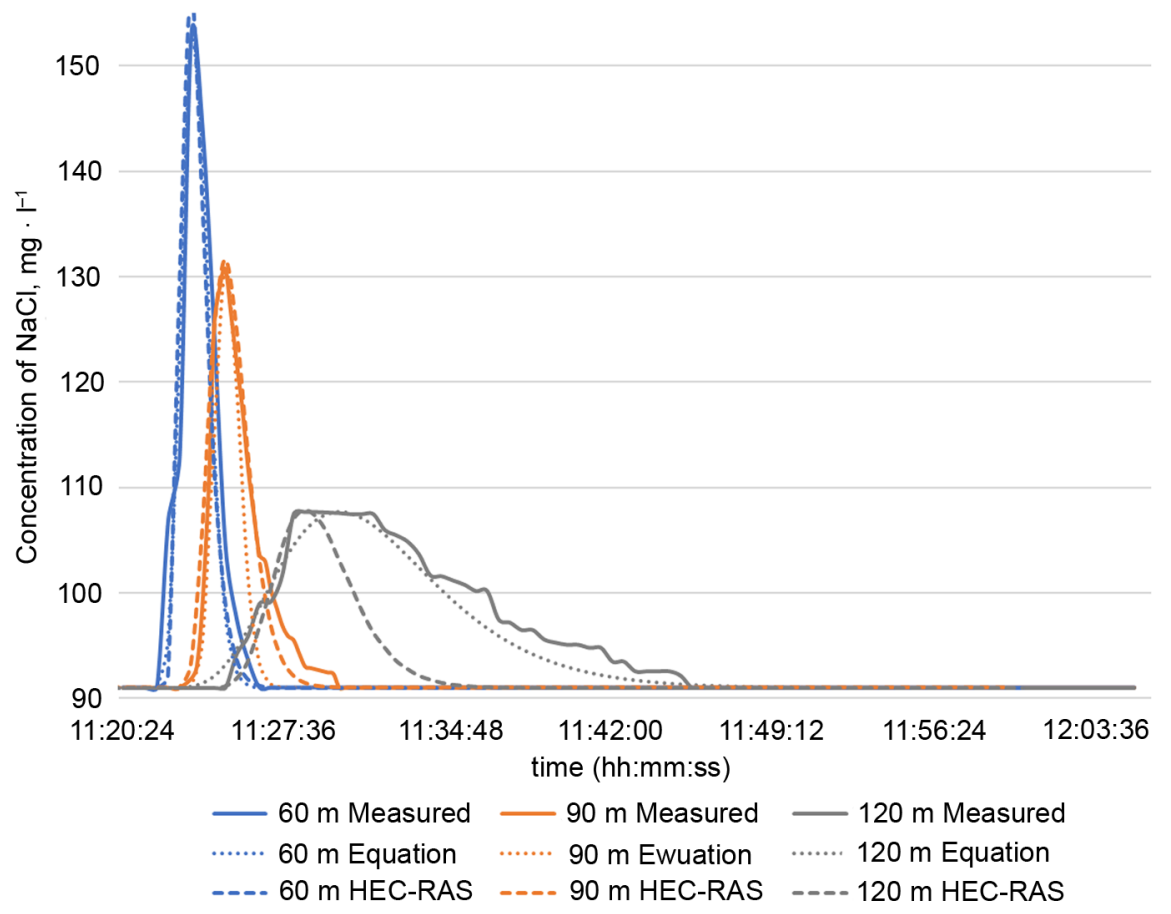

Fig. 9. The course of tracer over time in the Okna river, in June 2019, injected amount: $2 \mathrm{~kg} \mathrm{NaCl}$; distance from place of application: $60,90,120 \mathrm{~m}$; water flow $Q=0.201-0.311 \mathrm{~m}^{3} \cdot \mathrm{s}^{-1}$

177.5

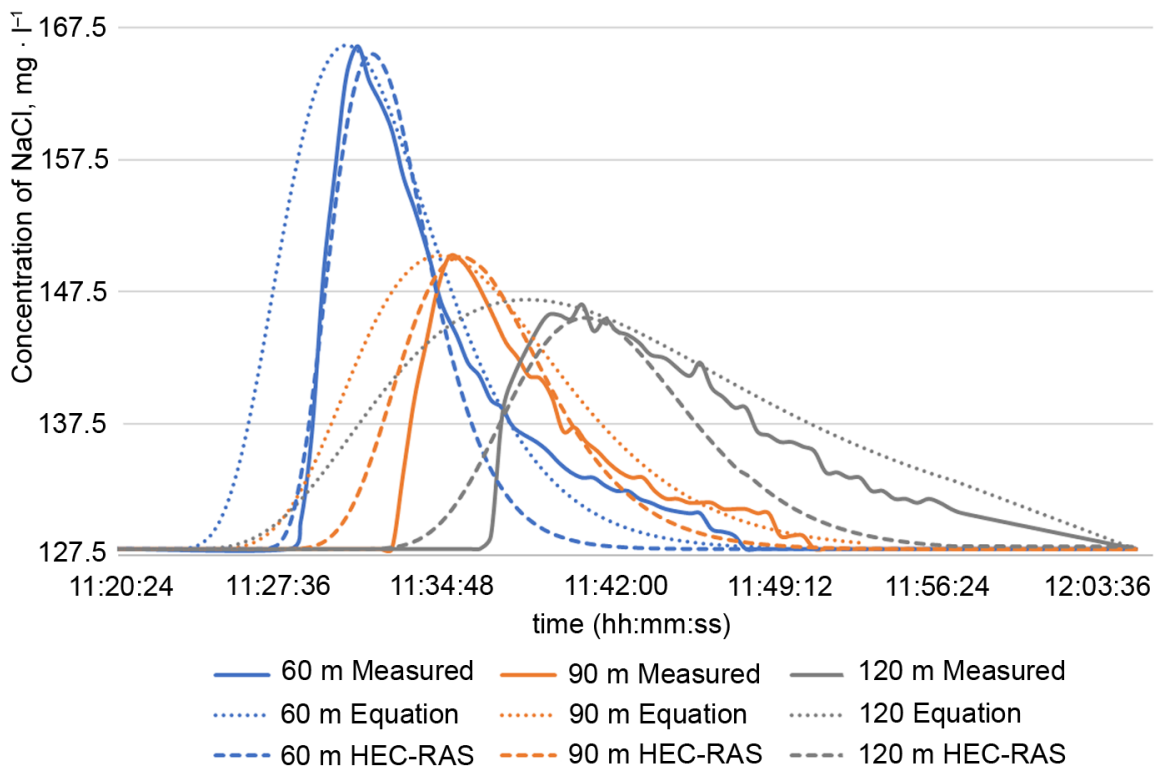

Fig. 10. The course of tracer over time in the Okna river, in October 2019; injected amount: $2 \mathrm{~kg} \mathrm{NaCl}$; distance from place of application: $60,90,120 \mathrm{~m}$; water flow $Q=0.049-0.087 \mathrm{~m}^{3} \cdot \mathrm{s}^{-1}$ 
In general, results of HEC-RAS simulation are closer to the measured values than the results obtained via numerical solution of equation (3) (see: Table 1). Several authors present and apply equation (3) as one of the possible tools to determine longitudinal dispersion coefficient. Nevertheless, comparison of results calculated and simulated by HEC-RAS showed acceptable correlation, enabling the determination of the coefficient. Furthermore, HEC-RAS model can prove very sensitive in predicting dispersion, even in case of vegetation impact on water movement in the watercourse.

Values of longitudinal dispersion coefficient are higher for HEC-RAS model almost in all cases (except in the profile 4 in October). Differences varied between 0.097 and $1.193 \mathrm{~m}^{2} \cdot \mathrm{s}^{-1}$. A lower dispersion coefficient value means higher dispersion of the substance in water, and higher value means lower dispersion of the substance in water. Average value of coefficient simulated using the HEC-RAS model in the part of river under consideration was 0.415 $\mathrm{m}^{2} \cdot \mathrm{s}^{-1}$. This value is comparable to the results of Malina watercourse $-0.607 \mathrm{~m}^{2} \cdot \mathrm{s}^{-1}$ (Sokac and Veliskova, 2016), which is comparable to the Okna river. Several other small rivers with similar discharges were studied, with comparable results of dispersion coefficient from field experiments e.g. Rybárik and Lesný range between $0.2-0.7 \mathrm{~m}^{2} \cdot \mathrm{s}^{-1}$, Malá Nitra range from 0.05 to $2.5 \mathrm{~m}^{2} \cdot \mathrm{s}^{-1}$ (Veliskova et al., 2013), Ondava $0.84-1.36 \mathrm{~m}^{2} \cdot \mathrm{s}^{-1}$ and Jalovecký river $1.5-2.5 \mathrm{~m}^{2} \cdot \mathrm{s}^{-1}$. Higher values of dispersion coefficients were noted for rivers with higher discharges, e.g. Hron from 6 to $10 \mathrm{~m}^{2} \cdot \mathrm{s}^{-1}$ (Veliskova and Pekarova, 2006), Svitavy from 4.73 to $6.66 \mathrm{~m}^{2} \cdot \mathrm{s}^{-1}$ or about $8.0 \mathrm{~m}^{2} \cdot \mathrm{s}^{-1}$ for channels on Žitný Ostrov (Danecek et al., 2002). This comparison suggests that this may be a relevant figure, which may be considered in the future. Evaluating dispersion in rivers is difficult, because every river and every reach of river has different conditions of vegetation, flow or velocities. Sokac and Veliskova (2016) mentioned that the method for determining longitudinal dispersion coefficient, as a key parameter, should be consistent in the way it is used by a model to achieve a maximum match between the measured and the modeled data. They also assume that model calibration is needed to complete the forecast.

\section{CONCLUSION}

This article presents results from field experiments, outputs of the HEC-RAS model and of calculations by equation, which confirm the problematic exact prediction of the passage of pollutant in the watercourse. The model predicts coefficient of dispersion higher than the one calculated from the equation, but this prediction better fits the measured data of field experiment conducted for Okna river. The longitudinal dispersion coefficient values calculated from the equation vary between 0.093 and $1.08 \mathrm{~m}^{2} \cdot \mathrm{s}^{-1}$, and those modelled by HEC-RAS differ from 0.220 to $1.850 \mathrm{~m}^{2} \cdot \mathrm{s}^{-1}$. It is very difficult to assess whether the resulting longitudinal dispersion coefficient values in streams are realistic. Partially it is possible to rely on numerical calculations and simulations from HEC-RAS model as was described by other authors. Resulting values were negatively influenced mainly by dead zones in flow, the occurrence whereof has been known before each measurement. Those zones are formed by bank and bed vegetation with several growing stages during the year. Therefore, different values of dispersion coefficient for the watercourse should be used within the year.

The obtained coefficients have a broad range of applications. The main use of the computed coefficients is for the simulation of accidental pollution spread in rivers. Also, they can be applied to streams with similar characteristics, as it has been mentioned above in the article. The presented results demonstrated an important role of seasonal variation of longitudinal dispersion coefficient that must be assumed in any simulation of pollution spreading in rivers.

\section{ACKNOWLEDGEMENTS}

This work has received the support from the Research Support Scheme of the Slovak Research and Development Agency in the framework of project APVV16-0278.

\section{REFERENCES}

Abderrezzak, E. K. K., Ata, R., Zaoui, F. (2015). One-dimensional numerical modelling of solute transport in streams: The role of longitudinal dispersion coefficient. Journal of Hydrology, 527, 978-989. 
Manina, M., Halaj, P., Jurík, L., Kaletová, T. (2020). Modelling seasonal changes of longitudinal dispersion in the Okna river. Acta Sci. Pol., Formatio Circumiectus, 19 (1), 37-46. DOI: http://dx.doi.org/10.15576/ASP.FC/2020.19.1.37

Danecek, J., Ryl, T., Riha, J. (2002). Stanovení hodnoty koeficientu podélne hydrodynamické disperze ve vodních tocích řešením Fišerova integrálu. In Journal of Hydrology and Hydromechanics, 50(2), 104-113.

Drake, J., Bradford, A., Joy, D. (2010). Application of HEC-RAS 4.0 temperature model to estimate groundwater contributions to Swan Creek. Ontario, Canada, Journal of Hydrology, 389(3-4), 390-398.

Fisher, B. H., List, E., Koh, R., Imberger, J., Brooks, N. (1979). Mixing in Inland Coastal Waters. New York: Academic Press.

Gaiemo, G., Cheng, G. (2019). Mathematical modelling and application for simulation of water pollution accidents, Process Safety and Environmental Protection, 127, 189-196.

Hamidifar, H., Omid, H. M., Keshavarzi, A. (2015). Longitudinal dispersion in waterways with vegetated floodplain. Ecological Engineering, 84, 398-407.

Korosin, K. (1995). Disperzné koeficienty pre prirodzené profily povrchových tokov. Journal of Hydrology and Hydromechanics, 43(1-2), 93-101.

Mosiej, J., Skrzypski, J., Suchecka, T. (2019). Impact of the Łódź agglomeration on water quality indicators and load of pollutants in ner and warta rivers, in the period 1995-2011. Acta Sci. Pol. Formatio Circumiectus 18(4), 2019, 25-35.

Nawiesniak, M. (2018). Hydromorphological and landscape assessment of the Białka river valley. Acta Sci. Pol.Formatio Circumiectus 17(2) 2018, 3-11.
Parker, R. S., Adams, K. S., Lammers, W. R., Stein, D. E. (2019). Targeted hydrologic model calibration to improve prediction of ecologically relevant flow metrics, Journal of Hydrology, 573, 546-556.

Sokac, M., Veliskova, Y. (2016). Analytical Solution of the Advection-Dispersion Equation Using Asymmetrical Pollution Distribution. IOP Conference Series: Earth and Environmental Science, 221.

Taldei, S., Camporeale, G., Perucca, E., Ridolfi, L. (2010). Longitudinal dispersion in vegetated rivers with stochastic flows. Water Resources, 33, 562-571.

Veliskova, Y., Pekarova, P. (2006). Numerical modelling of accidental pollution spreading at upper part of Hron River. In Proc. XXIII. Conference of the Danubian countries on the hydrological forecasting and hydrological bases of water management. ISBN 86-80851-07-8, (eds. Bruk, S., Petkovic, T.), CD ROM, Belgrade, Serbia, 10 p.

Veliskova, Y., Halaj, P., Sokac, M. (2013). Citlivost' modelu HEC-RAS na zmenu disperzného koeficientu vstupného parametru modelu. Acta Hydrologica Slovaca, 14(2), 392-401.

Walker, B. J., Baumgartner, C. P., Gerba, C. P., Fitzsimmons, K. (2019). Surface Water Pollution. Environmental and Pollution Science, Third Edition, 261-292.

Wang, F., Huai, X., Wang, J. (2017). Physically sound formula for longitudinal dispersion coefficients of natural rivers. Journal of Hydrology, 544, 551-523.

\title{
MODELOWANIE SEZONOWYCH ZMIAN DYSPERSJI WZDŁUŻNEJ W RZECE OKNIE
}

\begin{abstract}
ABSTRAKT

\section{Cel badań}

Choć zagadnienie badania transportu zanieczyszczeń wzdłuż cieków wodnych nie jest niczym nowym, to ze względu na poziom skomplikowania, wciąż wymaga ono doprecyzowania w odniesieniu do poszczególnych cieków wodnych. Przedstawione badania mają na celu ustalenie wartości dyspersji podłużnej i koncentruje się na porównaniu sezonowej zmienności dyspersji wzdłużnej, którą determinują naturalne warunki koryta rzecznego.
\end{abstract}

\section{Materiat i metody}

Dyspersję znacznika zanieczyszczeń symulowano za pomocą modelu HEC-RAS i jednowymiarowego równania dyfuzji-adwekcji. Określenia współczynnika dyspersji wzdłużnej dokonano na podstawie eksperymentów ze znacznikami (2 kg NaCl w $\left.101 \mathrm{H}_{2} \mathrm{O}\right)$ przeprowadzonych w marcu, sierpniu i październiku $2019 \mathrm{r}$. Obie metody zastosowano do rzeki Okna zlokalizowanej na Nizinie Wschodniosłowackiej.

\section{Wynik i wnioski}

Wyniki badań pokazały, że modelowanie HEC-RAS koreluje ze zmianami dyspersji oraz zmianami roślinności w rzece. Szacowany współczynnik dyspersji wzdłużnej dla rzeki Okna obliczony na podstawie równania w ciągu roku mieścił się w zakresie od 0,093 do $1,08 \mathrm{~m}^{2} \cdot \mathrm{s}^{-1}$, zaś według HEC-RAS wynosił od 0,220 do 
$1,850 \mathrm{~m}^{2} \cdot \mathrm{s}^{-1}$. Wyniki mogą reprezentować różne wartości dyspersji wzdłużnej symulowane za pomocą modelu lub za pomocą równanie. Uzyskane współczynniki mają szerokie zastosowanie. Są szczególnie przydatne do jako dane wejściowe do symulacji rozprzestrzeniania się przypadkowego zanieczyszczenia w rzekach. Można je również odnieść do strumieni o podobnych właściwościach. Wyniki badań wykazały ważną rolę sezonowej zmienności współczynnika dyspersji wzdłużnej, co należy uwzględnić w symulacji rozprzestrzeniania się zanieczyszczeń w rzekach.

Słowa kluczowe: dyspersja wzdłużna, HEC-RAS, znacznik, badania terenowe 